\title{
LEGISLATIVE PROGRAM CONGRESS SHOULD ADOPT FOR IMPROVEMENT OF AMERICAN WATERWAYS
}

\author{
By Joseph E. Ransdell, LL.D., \\ Member of the Rivers and Harbors Committee of Congress from the Fifth \\ Louisiana District, and President of the National \\ Rivers and Harbors Congress.
}

There has been much discussion about the improvement of the waterways of the United States during recent years, and great and general interest has been aroused on the subject. A number of waterway associations have been formed to press upon Congress the importance of specific projects; and though local in character, many of them represent very large sections and have gathered into their ranks great numbers of men and much capital. Among the most prominent of these associations are: The Western Waterways Asociation, which aims to unite in a concentrated effort for the common weal all the streams of the Mississippi Valley; the Lake Carriers' Association, which carefully watches all lake interests; the Interstate Mississippi River Levee Association, which looks after the levees of that river from Cairo to the Gulf; the Ohio Valley Improvement Association, whose object is to deepen the Ohio River to nine feet from Pittsburg to Cairo; the Upper Mississippi River Improvement Association, which wishes to see good navigation on the father of waters from St. Louis to St. Paul; the Lakesto-the-Gulf Deep Waterway Association, which proposes to connect Lake Michigan and the Gulf of Mexico by a channel of fourteen feet ; the Missouri Valley River Improvement Association, which expects to have not less than eight feet and hopes to have twelve feet in that great stream from its mouth to Omaha ; the Interstate Inland Waterway Association, which seeks to join the Mississippi River and the Rio Grande by a nine-foot canal, linking together the various waterways along the coasts of Louisiana and Texas; the Columbia River Association, which hopes to overcome the obstac'es to navigation in that mighty river by a canal and locks at The Dalles and by rock dredging above; the Atlantic Deeper Waterways Association, which advocates a continuous inland route for our naval and merchant ships from Boston to Jacksonville, Fla., thereby avoid- 
ing all dangers of the open ocean, and which hopes ultimately to cross the Florida peninsula and skirt the Gulf coast to New Orleans; the Tennessee, the Cumberland, the Ouachita, the Red, the Trinity, the Chattahoochee, the Cape Fear rivers associations, and many others.

In addition there has been the most vigorous and determined effort on the part of maritime interests in the great seaport cities, like Philadelphia, New York, Boston, Baltimore, Norfolk, Savannah, Tampa, Mobile, New Orleans, Galveston, Los Angeles, Oakland, Portland, and Seattle.

All these associations have labored with much energy and with more or less success for their own particular projects without any concert of action; and it was to bring about a united action of all waterway interests that the National Rivers and Harbors Congress was organized in the fall of rgor and reorganized on its present basis in January, I906. This association is composed of large numbers of individuals, corporations, commercial organizations, and waterway associations from thirty-three states, and it is in every sense of the word national. It does not advocate the improvement of any particular project, but seeks to unite all friends of waterways in an effort to have Congress adopt a definite policy that will provide for the complete improvement within ten years of every worthy and deserving water course on our seaboards, lakes, and iriterior. It stands for a policy, not a project. Its slogan at the great reorganizing convention of January, 1906, in Washington, D. C., was: "An annual rivers and harbors bill carrying at least fifty million dollars:" and again that slogan was repeated at the much greater convention at the nation's capital in December, 1906, while Congress was in session. Largely as the result of sentiment aroused through its efforts, and the splendid co-operation of all other waterway associations and interests, the greatest rivers and harbors bill in our history was enacted in June, 1907. This association will hold another great convention at Washington in December, 1907 (before this article is published), and again it will stand for "An annual rivers and harbors bill carrying at least fifty million dollars."

These river and harbor bills for the past ten years were enacted by Congress triennially: in $1896,1899,1902$, and 1905 . Then, through the united efforts of all our waterway associations and their friends, came the bill of 1907 , at the end of two instead of 
three years. The next convention of the National Rivers and Harbors Congress will insist in the strongest possible way upon a bill every year, and will do its utmost to have one enacted next spring at the first session of the Sixtieth Congress. The annual feature of these bills is regarded as of paramount importance.

What is the reason for all this agitation and interest? Is it sentimental or is it founded on solid business principles? Undoubtedly on the latter. There is no sentiment about it. The people are very much in earnest. They have ascertained by experience and study that transportation by water is not only much cheaper than by rail, but also much quicker. When freight is loaded in boats on lakes, canals or rivers it moves promptly at a speed of from five to ten miles an hour to its destination, where it is quickly discharged, and the boat started on another trip. When loaded on cars, it frequently remains on a sidetrack for some time, and after reaching its terminus, the cars are again sidetracked and used for days and weeks as storage warehouses. The best authorities say that the average movement of freight by rail in our country is only twentyfive miles per day-only about one mile an hour. I have never seen statistics as to the movement by water, but anyone familiar with the enormous commerce on the Great Lakes, where tenthousand-ton ships make the round trip from Buffalo to Duluth and return-two thousand miles-every eight to nine days, carrying heavy loads each way, can see that the movement there is considerably over 200 miles a day.

At my home, Lake Providence, La., on the banks of the Mississippi, 400 miles from New Orleans, we have large steamers, and also the railroad, but we never think of shipping bulky articles by rail that can come or go by boat. Cotton is our principal product, and we ship it to New Orleans with the certainty that it will reach there and be in the consignee's hands within three days. If sent by rail, it would be big luck to have it reach the consignee in ten days. The delivery by boat in three days is certain and by rail in ten day's is most uncertain. I do not think sufficient stress has been laid upon the greater rapidity of freight movements by water than by rail, and invite a study and comparison thereon. It is the old story of the race between the tortoise and the hare. The former won in spite of his slow movements because he kept going. And the boats win for the same reason. They do not slumber on side tracks, 
as the hare and the railroad, but keep moving like the patient tortoise and win every time.

As to the relative cost by the two methods, there can be no difference of opinion. The Interstate Commerce Commission reported that the average cost of moving freight by rail in 1906 was 7.48 mills per ton per mile. The statistical report on the lake commerce for 1906 by Colonel Davis, U. S. E. C., shows it cost to move over 5I,000,000 tons through the Sault Ste. Marie Canal last year .84 of one mill per ton per mile, or one-ninth of the average rail rate. Major William L. Sibert, now a member of the Panama Commission, for years United States Engineer at Pittsburg, and one of the most accomplished members of the engineer corps of the army, estimates that in 1905, in spite of the unsatisfactory condition of the Ohio River, it cost to move freight from Pittsburg to Louisville .76 of one mill per ton per mile, or one-tenth the average rail rate, and from Louisville to New Orleans .67 of one mill per ton per mile, or one-eleventh of the rail rate. From the best information I can get after a careful study of the subject, I am convinced that waterway transportation in this country, under favorable conditions, costs only about one-sixth as much as the average cost by rail.

The above remarks apply to the lakes and rivers and furnish unanswerable arguments for their improvement; but there are just as good reasons for giving our harbors the greatest available depth and placing them on a par with the great foreign ports which receive our splendid commerce. The larger the ship the greater its carrying capacity and the cheaper its rates of freight. Vessels drawing twenty-eight to thirty-two feet and carrying eight to twelve thousand tons can and do carry freight very much cheaper than those drawing twenty-two to twenty-four feet and carrying three to four thousand tons. The ocean rates to-day on the immense steamers plying at our great harbors, which have been deepened to thirty and more feet, are from one-third to one-fourth the rates of twentyfive years ago, when steamers drew only twenty-two to twenty-three feet; and this saving of 300 to 400 per cent in transportation charges is directly due to the improvement of these harbors. Our government never made a wiser expenditure of its funds. The farmer on the western plains and the cotton grower of the South get the direct benefits of these cheap rates, for his produce is worth on his farm its price at Liverpool or Antwerp less the cost of trans- 
portation from the farm to those great markets. Every citizen of the Union is benefited. Practically all our waterway expenditures have been profitable investments. They have returned in reduced freight rates to the American people from 100 to 200 per centum every year. And yet while appropriations for most purposes of government have been liberal, those for waterways have been stingy and unbusinesslike in the extreme. During our entire history as a nation, to the close of the last fiscal year, on all our waterways of every sort, including those in far away Hawaii, the total expenditure was only $\$ 523,330,232$; yet we gave the navy during the past five years $\$ 490,199,715$. Nearly as much to the navy in five years as to rivers and harbors during the II 8 years of our national existence!

For the five years ending June 3oth last all our seaboard and lake harbors, our lakes, rivers, and canals received an average annual appropriation of only $\$ 23,425, \mathrm{I} 3 \mathrm{I} \cdot 30$ - less than 3 per cent of the total expenses of government, and a sum entirely inadequate to their merits and needs. The December convention of the National Rivers and Harbors Congress will insist that this appropriation shall hereafter be not less than fifty million dollars every year.

The rivers and harbors act of last session carried an appropriatian of $\$ 34,631,612$ in cash, and authorized contracts to the amount of $\$ 48,834,526$, making a total of $\$ 83,466$, 138 . Under the authorization clause, various works will be placed under contract and will be paid for from year to year as appropriations are hereafter made by Congress. In some instances it will be seven or eight years before these contracts are completed, hence some of the sums authorized in this bill will not be actually appropriated for several years.

This bill was the wisest and most businesslike rivers and harbors bill ever enacted in our country. It provided all sums necessary for the completion of some most important works, notably at the harbors of Boston and Baltimore, the channels at the mouths of the Mississippi and Columbia rivers, the new lock at Sault Ste. Marie, and the new channel in the Detroit River. These six projects required $\$ 24,426,194$ to complete them, and the total was carried in the bill. Work was already in progress, under the act of 1905, at Boston and Baltimore, and on the Mississippi and Columbia rivers, but the Sault lock and the Detroit River project were entirely new, and the amount they received was $\$ 12,870,950$. These six great and deserving projects are now out of the way, and need no considera- 
tion in future bills. Let us compare the wisdom with which they were handled in the bills of 1905 and 1907 with some other waterway projects.

We undertook to improve the Harlem River in New York City, within the shadow of Wall Street, in 1878 , twenty-nine years ago, on a plan estimated to cost $\$ 2,700,000$. During those twentynine years about $\$ \mathrm{I}, 350,000$ have been appropriated and spent, and the work is only about one-half finished. The commerce on the Harlem River last year was $9,998,02$ I tons, valued at $\$ 270,2$ ro,309. At the present rate of appropriation it will require another twentynine years to complete the project.

About twenty-three years ago we began a project for six-foot slack-water navigation on the Warrior and Tombigbee rivers in Alabama to connect with as rich coal mines as there are on earth and to supply cheap coal to the whole Gulf coast, to our navy, and to the great ocean fleet of that section. At first the project was estimated to cost $\$ 3,000,000$, but subsequently the plan was changed and the estimated cost increased to $\$ 6,000,000$. After twenty-three years it still remains far from completion.

In $1875-76$, some thirty-two years ago, a project providing for a six-foot slack-water navigation on the Ohio was adopted and work begun thereon. It has proceeded. with a snail's pace. Out of fifty-two locks and dams provided for in this project only six have been completed and four others are in process of construction. The project has been changed to a nine-foot depth instead of six, and the estimated cost of completion is $\$ 63,000,000$. If this gigantic and most meritorious work is continued at the same rate as for the past thirty-one years, it will not be finished by the close of this century. It is true that a little better progress has been made during the past seven years, and at the present rate we may hope to see the Ohio canalized in about fifty years.

These are striking examples of the extreme slowness and unbusinesslike way in which river and harbor works have been carried on. It was not the fault of the rivers and harbors committee. They did as well as they could with the limited amounts at their disposal. Public sentiment did not seem to be with them in the past, and they could not provide the large sums necessary to push meritorious works to speedy completion. And yet the clamor from many communities was so great that they could not avoid making 
partial appropriations for prosecution of projects which could not be entirely finished, although they realized how much wiser it would have been to confine their efforts to fewer works and finish them as they went along. This policy of completing old projects before undertaking new ones was to a great extent applied in the act of 1907, and is much wiser.

Now what should be the legislative program that Congress should adopt for the improvement of American waterways? In my opinion, one that will provide for the proper improvement within the next ten years of all waterway projects along the seaboard, the lakes, and the interior rivers that are really worthy of it, and whose improvement seems warranted by prospective benefits to commerce. I fix ten years as the period because:

First. The cost of these improvements will be considerableprobably half a billion dollars for the projects already surveyed, which amount would require an appropriation of fifty millions a year for that period.

Second. The character of the work in most cases is such that it must proceed slowly, and even if the total sum were available it would require about ten years to finish many of the greater projects. Some of them are fairly comparable in difficulty of detail and execution with the new Erie and Panama canals, and the engineers of those two great works estimate for their completion at least ten years from inception.

Third. The most ardent enthusiast of waterways is willing to admit that in practical government its various branches should move along "pari passu," and all he expects is a reasonable legislative program which places waterway improvement on a parity with other government works.

Now would it be unreasonable to expend fifty millions, or even one hundred millions, a year for improving our waterways, materially benefitting commerce, reducing freight congestions and cheapening freight rates, so that every citizen of the Union would feel its good effects? By no means. It would be most reasonable and wise. Let us institute a few comparisons on which to base an opinion. For the five years ending June 30, 1907, fortifications received an annual appropriation of $\$ 6,761,489$, nearly one per cent of all expenses of government; the army received $\$ 80,509,480$, or about Io per cent; the navy, $\$ 98,039,942$, or about i2 per cent; and pen- 
sions, $\$ 140,851,836$, about 17 per cent; while rivers and harbors received an average of only $\$ 23,425$, I21.30 a year as above set out, or less than 3 per cent. Commerce is surely as important as war; and as we are now giving to war and its rewards-fortifications, the army, the navy, and pensions- $\$ 336,168,748$ a year-over 40 per cent of the expenses of government-and only about 3 per cent to rivers and harbors, surely we can afford to give to our waterways for commerce at the very lowest calculation at least fifty millions, or 7 per cent. If we made it one hundred millions it would be only 14 per cent of our annual expenditures and still not be on a par with those made for war.

How shall we secure this program? The present method of passing rivers and harbors bills every two or three years, which in many instances makes only partial provision for specific projects and does not commit or bind succeeding Congresses to complete them, is lacking in that continuity of plan and purpose essential to success. This is forcibly illustrated by the cases of the Harlem, the Warrior-Tombigbee, and the Ohio Rivers above cited, and there are a great many others exactly similar. The last bill, as stated, was a vast improvement in this respect and made definite provision for the final completion of six great projects. If we could have such a bill every year as that of last June, each providing for the completion on the continuous contract method of several projects, the work would be well in hand very soon, and we could expect the consummation of our hopes within a few years:

I am strongly of the opinion that for the present the best plan for Congress to pursue is to pass a rivers and harbors bill at the coming session carrying in cash and authorizations from fifty to sixty million dollars and making provision:

First. For the completion of several of the more worthy projects under way, whose aggregate cost will not exceed one-third of the bill; say about eighteen to twenty millions.

Second. For the active prosecution on a generous scale of other great works now under construction, whose total cost is too great to permit of provision for complction in one bill.

Third. Adopting plans for and beginning work on some very important new projects not yet adopted; and

Fourth. Ordering surveys for proposed projects of much apparent merit. 
I would like to see the completion of as many projects as possible definitely provided for in this bill and the work placed under continuing contract, so that no change of administration or policy could jeopardize the success of a work or indefinitely delay it, after it had once been adopted and begun, as was the case with the Harlem, the Warrior-Tombigbee, and the Ohio Rivers, as explained above.

It would not be feasible without a complete change in the present methods to provide in one bill for the completion of colossal projects like the Ohio River, which will cost over $\$ 60,000,000$, or the lakes to the Gulf deep-waterway, which will cost much more than the Ohio; but if the bill of next spring definitely adopts the plan for nine feet from Pittsburg to Cairo and makes an appropriation of two and a half millions in cash and five millions in authorizations for the completion of six or seven designated locks and dams on the Ohio, and does as well for the lakes to the Gulf deep-waterway, it would place those two truly great projects on a fairly safe basis, and reduce to a minimum the chances of further delay in their completion.

The same would be true of other projects of great magnitude and cost. They could not be fully provided for, but might be adopted as a whole and good round sums be appropriated to prosecute the work thereon. The rivers and harbors bill of the following year could make further provision for them, and in a few years they would be finished. Of course this theory is based upon the idea that we are to have an annual rivers and harbors bill in the future, and that it is to carry an average of at least fifty million dollars every year. If we are to follow the past method of a bill every two or three years, I see no hope for the speedy improvement of our great internal river systems. The harbors and connecting channels on seaboards and lakes will be promptly finished in the future just as they have been in the past, for they are railroad terminals, but our rivers which are railroad competitors will not be completed under the present methods within any reasonable period of time. We must change the method. We must pass rivers and harbors bills every year, and they must carry at least two and a half to three times as large appropriations as in the past. That is the only sure plan, in my judgment-a rivers and harbors bill every year carrying not less than fifty million dollars. 
Transportation is one of the most important questions in the commercial world, and its importance will increase with the growth of wealth and population. Quick and easy transfer and exchange of commodities between different communities is the very life of trade. The cotton grower and lumberman of the South, the grain and meat farmer and lumberman of the West, must send their bulky products to our populous middle and eastern sections and to Europe, receiving in exchange innumerable articles of manufacture, etc. Large numbers of people are constantly moving from place to place, and the mail must be carried with rapidity. The more enlightened and civilized a people becomes the more complex and important are their transportation proiblems. If all communication with the outside world were cut off from New York City for a week and no food supplies were sent in by water, rail, or earth roads, many people would starve. During the past two years the whole country has been aroused on this subject as never before. Many communities have suffered terribly because a lack of transportation facilities prevented them from moving their commodities. Congress has passed the rate bill, and many state legislatures have enacted laws intended to benefit transportation. Everybody is talking about the subject in some form. Many people think repressive legislation against the railroads will solve it, and others that a complete and thorough development of our waterways would be the panacea for all our transportation ills. None of these people are entirely right, and all have more or less right on their side. One feature of the question is admitted by all and that is its national character. Nature recognized no state lines in laying out her mighty waterways, and man had as little regard for them in constructing railroads. Our waterways and railroads are interstate. They extend far beyond the confines of states and should be controlled by the nation rather than by the states.

In my judgment the great importance of this subject warrants the creation by the next Congress of a department of transportation, with full charge of all matters relating to highways, railroads, and waterways. Its chief should be a Cabinet officer-the Secretary of Transportation-and his duties should be limited to subjects connected with transportation.

At the present time the Interstate Commerce Commission which executes our laws relating to public carriers is an independent 
body, not connected with any of the departments. Waterway improvements are under the War Department, and are an incident or a side issue not naturaliy connected with the main business of that great department; and such meager legislation as we have on the subject of highways is executed by the office of good roads of the Agricultural Department. If all these matters were consolidated in one department their importance would be greatly emphasized and they would receive more consideration at the hands of Congress. How can the Secretary of War, with the manifold and difficult duties imposed upon him, be expected to give much attention in Cabinet council, in his reports to Congress, and elsewhere to the needs of a side issue like waterways? How can the Secretary of Agriculture insist upon good roads legislation when purely agricultural subjects make such a drain upon him? And what Cabinet officer is there to handle railroad questions? Let us create this department of transportation by all means. It would have plenty to do and would not be exceeded in importance and beneficent effects by any of the older departments.

Pending action on this department, I sincerely hope the coming session of Congress will create a national waterways commission similar to the internal waterways commission appointed by the President last spring. It should be required to study the waterways of America on seaboard, lake, and interior, and also those of the Old World, with a view to advising Congress how to establish the best and most comprehensive system of water transportation for our country. In doing this our principal waterways should be visited and carefully inspected; experts and business men should be advised with; and all scientific knowledge availed of. The commission should visit and study on the spot the waterways of Europe and elsewhere, so as to get the benefit of all the world's experience on this subject. And the result of its studies and conclusions should be submitted to Congress. Its powers should be limited to obtaining information in regard to waterways, together with the allied subjects of forest preservation and irrigation, and giving advice concerning them to Congress. If the department of transportation is created, this commission should be one of its important bureaus.

To sum up, I would say that the legislative program which Congress ought to adopt at its next session for the improvement of American waterways should be: 
First. The prompt passage of a rivers and harbors bill carrying in cash and authorizations not less than fifty million dollars.

Second. The creation of a national waterways commission to study our waterways and advise Congress thereon.

Third. The creation of a department of transportation with control of all matters relating to highways, railroads, and waterways. 